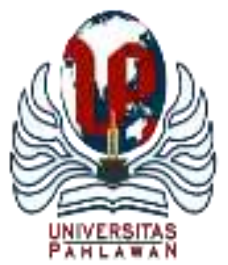

Edukatif : Jurnal Ilmu Pendidikan Volume 3 Nomor 6 Tahun 2021 Halm 4568 - 4583

EDUKATIF: JURNAL ILMU PENDIDIKAN

Research \& Learning in Education

https://edukatif.org/index.php/edukatif/index

\title{
Membangun Inovasi Organisasi: Antara Kepemimpinan Transformasional dan Proses Manajemen Pengetahuan
}

\author{
Dhaniel Hutagalung ${ }^{1 凶}$, Dewiana Novitasari ${ }^{2}$, Nelson Silitonga ${ }^{3}$, Masduki Asbari ${ }^{4}$, \\ Nana Supiana 5 \\ Sekolah Tinggi Ilmu Ekonomi Insan Pembangunan, Indonesia ${ }^{1,2,3}$ \\ STMIK Insan Pembangunan, Indonesia ${ }^{4,5}$ \\ E-mail : dhanielhutagalung@gmail.com ${ }^{1}$, dhewiediosa@yahoo.co.id ${ }^{2}$, nelsonsilitonga76ueu@ gmail.com $^{3}$, \\ kangmasduki.ssi@gmail.com ${ }^{4}$, nn.supiana@ gmail.com $^{5}$
}

\begin{abstract}
Abstrak
Faktor kelemahan praktik leadership dan learning disebutkan sebagai di antara faktor penghambat kinerja inovasi organisasi. Mengingat masalah ini, penelitian ini mencoba untuk menyelidiki praktik dan efek kepemimpinan transformasional terhadap proses manajemen pengetahuan, dan juga pengaruh implementasi proses manajemen pengetahuan (dengan dimensi knowledge acquisition, knowledge dissemination, dan knowledge application) terhadap kinerja inovasi di industri manufaktur. Pendekatan Partial Least Square (PLS) digunakan untuk menganalisis data yang diperoleh dari 117 karyawan dari salah satu perusahaan manufaktur di Tangerang Indonesia. Hasil yang diperoleh menunjukkan bahwa kepemimpinan transformasional memberi pengaruh yang positif dan signifikan terhadap ketiga dimensi proses manajemen pengetahuan dan kinerja inovasi organisasi. Walaupun demikian, penelitian ini menemukan fakta bahwa di antara ketiga dimensi proses manajemen pengetahuan, hanya aplikasi pengetahuan yang berpengaruh signifikan terhadap kinerja inovasi organisasi. Dari perspektif teoritis, hasil penelitian ini memberikan bukti empiris tentang peran positif dan signifikan dari praktik kepemimpinan transformasional untuk meningkatkan kinerja inovasi perusahaan manufaktur. Sedangkan, dari perspektif manajerial, hasil penelitian ini memberikan gambaran pengambil keputusan di perusahaan manufaktur dengan pemahaman yang lebih baik tentang bagaimana praktik kepemimpinan transformasional dan memperbaiki proses manajemen pengetahuan.
\end{abstract}

Kata kunci: Kinerja inovasi, kepemimpinan transformasional, proses manajemen pengetahuan.

\begin{abstract}
The weakness factor of leadership and learning practices is mentioned as one of the inhibiting factors for organizational innovation performance. Given this problem, this study attempts to investigate the practice and effect of transformational leadership on the knowledge management process, as well as the effect of the implementation of the knowledge management process (with the dimensions of knowledge acquisition, knowledge dissemination, and knowledge application) on innovation performance in the manufacturing industry. Partial Least Square (PLS) approach was used to analyze data obtained from 117 employees of a manufacturing company in Tangerang, Indonesia. The results obtained indicate that transformational leadership has a positive and significant impact on the three dimensions of the knowledge management process and organizational innovation performance. However, this study finds that among the three dimensions of the knowledge management process, only knowledge application has a significant effect on organizational innovation performance. From a theoretical perspective, the results of this study provide empirical evidence about the positive and significant role of transformational leadership practices to improve the innovation performance of manufacturing companies. Meanwhile, from a managerial perspective, the results of this study provide an overview of decision makers in manufacturing companies with a better understanding of how to practice transformational leadership and improve knowledge management processes.
\end{abstract}

Keywords: Innovation performance, knowledge management, transformational leadership.

Copyright (c) 2021 Dhaniel Hutagalung, Dewiana Novitasari, Nelson Silitonga, Masduki Asbari, Nana Supiana

$\triangle$ Corresponding author

Email : dhanielhutagalung@gmail.com

DOI : https://doi.org/10.31004/edukatif.v3i6.1522

ISSN 2656-8063 (Media Cetak)

ISSN 2656-8071 (Media Online) 
4569 Membangun Inovasi Organisasi: Antara Kepemimpinan Transformasional dan Proses Manajemen Pengetahuan - Dhaniel Hutagalung, Dewiana Novitasari, Nelson Silitonga, Masduki Asbari, Nana Supiana DOI: https://doi.org/10.31004/edukatif.v3i6.1522

\section{PENDAHULUAN}

Pada tahun 2019 dunia telah berubah dengan kecepatan yang luar biasa. Transformasi yang konstan dan dinamika lingkungan begitu cepat sehingga kepemimpinan organisasi semakin rumit dari sebelumnya (Asbari \& Novitasari, 2020a; Johan et al., 2021; Novitasari, Supriatna, Asbari, et al., 2021a; Novitasari \& Asbari, 2021; Silitonga et al., 2021a). Pada saat ini, keteguhan dan keberadaan setiap sistem bergantung pada adanya hubungan yang kuat antar komponennya. Apalagi dalam konteks ini, peran kepuasan tenaga kerja sebagai salah satu komponen organisasi terpenting tidak dapat disangkal (Hutagalung, Asbari, et al., 2020; Jumiran et al., 2020; Novitasari, Asbari, Purwanto, et al., 2020; Novitasari, Asbari, \& Sasono, 2021; Nuryanti et al., 2020; Sutardi et al., 2020; Yuwono, Novitasari, Asbari, et al., 2020; Yuwono, Novitasari, Hutagalung, et al., 2020). Demikian juga secara internal individual, peran motivasi tidak bisa ditinggalkan dalam proses transformasi ini (Anggraeni et al., 2020; Johan et al., 2021; Purwanto; et al., 2019). Para peneliti secara konsisten menekankan pada pentingnya perluasan pengetahuan dalam organisasi yang mengarah pada pembentukan produk/layanan baru untuk mendapatkan keunggulan kompetitif (Asbari \& Novitasari, 2020a). Karena keberadaan pengetahuan penting bagi organisasi, mereka mencoba mengembangkan beberapa strategi untuk memperkuat pengetahuan stafnya. Manajer sumber daya manusia berusaha menemukan gaya kepemimpinan yang sesuai yang mendukung penerapan manajemen pengetahuan dan berkontribusi untuk memperkuat kinerja organisasi (Johan et al., 2021; Novitasari, Asbari, Sutardi, GazalI, et al., 2020; Novitasari, Sasono, et al., 2020; Novitasari \& Asbari, 2020b; Nuryanti et al., 2020). Studi di jalur ini telah menunjukkan bahwa berbagai gaya kepemimpinan memiliki efek yang berbeda pada implementasi proses manajemen pengetahuan. Kepemimpinan transformasional menciptakan motivasi di antara anggota untuk berbagi pengetahuan (Singgih et al., 2020). Selain itu, penelitian tersebut telah menunjukkan bahwa kepemimpinan transformasional menyebabkan terjadinya berbagi pengetahuan dan memiliki peran penting dalam meningkatkannya. Kepemimpinan transformasional memiliki pengaruh yang besar pada staf dan peran utamanya adalah dalam penerapan proses manajemen pengetahuan untuk meningkatkan kinerja organisasi (Asbari, 2019, 2020; Asbari, Novitasari, et al., 2020; Asbari, Santoso, et al., 2020; Asbari \& Novitasari, 2020b; Basuki et al., 2020; Hutagalung, Asbari, et al., 2020; Jumiran et al., 2020; Maesaroh et al., 2020; Novitasari, Asbari, Sutardi, GazalI, et al., 2020; Novitasari, Goestjahjanti, et al., 2020; Novitasari \& Asbari, 2020a; Silitonga et al., 2020; Yuwono, Wiyono, Asbari, et al., 2020, 2020; Zaman et al., 2020). Teori kepemimpinan transformasional mengklaim bahwa pemimpin memiliki perilaku tertentu yang mempercepat pemikiran inovasi staf dengan meningkatkan kinerja staf dan inovasi dan kinerja organisasi (Bass \& Riggio, 2006). Kehadiran kepemimpinan transformasional dalam organisasi menyebabkan kreativitas, pengambilan ide dan memfasilitasi perilaku inovatif dan pengambilan risiko (Asbari, Purwanto, et al., 2020; Asbari, Purba, et al., 2021; Novitasari, Asbari, Sutardi, Gazali, et al., 2020).

Memang, organisasi saat ini membutuhkan transformasi dan inovasi untuk bertahan hidup, lolos dari kematian dan stagnasi serta beradaptasi dengan lingkungan yang berubah dan tidak stabil. Hampir semua manajer berurusan dengan slogan "Anda akan menghadapi kematian kecuali jika Anda menjadi inovatif"(Aminbeidokhti et al., 2016). Masalah organisasi saat ini tidak dapat diselesaikan dengan solusi sebelumnya dan kondisi lingkungan menjadi begitu rumit, dinamis dan tidak pasti sehingga organisasi tanpa inovasi tidak dapat menjamin kehidupan jangka panjang mereka (Asbari, Novitasari, et al., 2021; Fikri et al., 2021; Novitasari, Asbari, Hutagalung, et al., 2021; Novitasari, Asbari, Putra, et al., 2021; Novitasari, Hutagalung, Amri, et al., 2021; Novitasari, Supiana, Supriatna, et al., 2021; Novitasari, Supriatna, Asbari, et al., 2021b; Silitonga et al., 2021b). Inovasi telah menciptakan kecenderungan yang drastis pada pengetahuan, keahlian dan keterlibatan karyawan sebagai masukan utama untuk proses penciptaan nilai. Namun, organisasi dengan fleksibilitas yang lebih besar terhadap inovasi sebagai reaksi terhadap perubahan lingkungan, dan 
organisasi yang mengembangkan kapabilitas baru yang membantu mereka mencapai kinerja yang lebih tinggi akan lebih sukses (Hutagalung, Asbari, et al., 2020; Hutagalung, Sopa, et al., 2020).

Oleh karena itu, penelitian ini berusaha untuk memahami faktor-faktor yang mempengaruhi implementasi yang tepat dari strategi tersebut berkaitan dengan pentingnya manajemen pengetahuan dan inovasi dalam organisasi (Agistiawati \& Asbari, 2020; Aman \& Asbari, 2020; Amri et al., 2021; Asbari, 2011, 2018; Asbari et al., 2019; Purwanto, Asbari, \& Santoso, 2020; Purwanto, Asbari, Santoso, Wijayanti, et al., 2020). Dalam hal ini, para peneliti menurut definisi kepemimpinan transformasional, manajemen pengetahuan dan inovasi telah mencoba untuk menyelidiki hubungan antara ketiga faktor tersebut dengan penelitian empiris dan memeriksa tingkat pengaruh kepemimpinan transformasional terhadap inovasi dan manajemen pengetahuan di salah satu perusahaan manufaktur di Indonesia. Tujuan dari penelitian ini, yang diharapkan dapat mengurangi ketidakpastian tentang hubungan ini. Oleh karena itu, pertanyaan penelitian utama dalam penelitian ini adalah:

Q1: Apakah kepemimpinan transformasional mempengaruhi proses manajemen pengetahuan?

Q2: Apakah proses manajemen pengetahuan mempengaruhi kinerja inovasi organisasi?

Dengan menjawab pertanyaan ini, diharapkan penelitian ini dapat memberikan kontribusi baik bagi akademisi maupun praktisi, karena mereka akan mengurangi kesenjangan dalam literatur relevan yang telah diidentifikasi di atas (Ooi, 2009). Selanjutnya hasil studi tersebut akan membantu manajer manufaktur untuk mengatasi salah satu faktor penghambat utama kinerja inovasi, yakni leadership dan learning. Untuk melakukannya, praktik manajemen pengetahuan telah diidentifikasi berdasarkan beberapa studi sebelumnya. Manajemen pengetahuan, telah diakui melalui tiga proses seperti yang dikemukakan oleh Darroch (2005) yaitu knowledge acquisition, knowledge dissemination, dan knowledge application. Penelitian ini diselenggarakan sebagai berikut: dimulai dengan pembahasan tentang hubungan antar variabel, dan kemudian hipotesis penelitian diperkenalkan. Bagian selanjutnya menjelaskan metode penelitian, analisis data, dan hasil, sedangkan bagian terakhir menyajikan kesimpulan, batasan kajian dan rekomendasi untuk penelitian selanjutnya.

\section{METODE PENELITIAN}

Menurut Creswell \& Creswell (2017), jika tujuan dari penelitian ini adalah untuk mengetahui hubungan pengaruh antar variabel yang diteliti, maka pendekatan kuantitatif adalah yang terbaik. Metode penelitian kuantitatif adalah cocok dalam menguji teori dan hipotesis melalui penggunaan seperangkat alat statistik (Creswell \& Creswell, 2017). Oleh karena itu, penelitian ini menggunakan metode survei untuk menguji hipotesis yang dirumuskan. Oleh karena itu, diadopsi kuesioner digunakan sebagai instrumen untuk mengumpulkan data yang dibutuhkan. Sampel penelitian ini terdiri atas 117 karyawan sebuah industri manufaktur di Indonesia. Dengan menggunakan simple random sampling, 237 kuesioner dikirim secara online kepada populasi. 117 kuesioner dikembalikan dan valid, yang membentuk tingkat tanggapan 49.4\% Menurut Roscoe's (1975) rule of thumb mengemukakan bahwa ukuran sampel antara 30 hingga 500 sudah sesuai untuk sebuah penelitian.

Karena sifat penelitian ini yang melibatkan efek dependen antara konstruk laten dan variabel manifes, model pengukuran reflektif cocok untuk penelitian ini (Hair Jr et al., 2017). Semua item yang diadopsi dinilai pada skala Likert lima poin dari 1 (sangat tidak setuju) sampai 5 (sangat setuju). Kepemimpinan transformasional diukur dengna menggunakan lima item (KEP1-KEP5) dari Bogler (2001). Kinerja inovasi diukur dengan menggunakan tujuh item (KIN1-KIN7) dari Cavusgil et al. (2003) dan Prajogo \& Hong (2008), serta telah divalidasi oleh (Yusr et al., 2017). Sedangkan untuk mengukur proses manajemen pengetahuan dalam organisasi, dua belas item diadaptasi dari Darroch (2003) dan Gold et al. (2001), serta telah divalidasi oleh (Yusr et al., 2017). Dua belas item tersebut didistribusikan ke dalam tiga 
4571 Membangun Inovasi Organisasi: Antara Kepemimpinan Transformasional dan Proses Manajemen Pengetahuan - Dhaniel Hutagalung, Dewiana Novitasari, Nelson Silitonga, Masduki Asbari, Nana Supiana DOI: https://doi.org/10.31004/edukatif.v3i6.1522

dimensi seperti yang dikemukakan oleh Darroch (2003), yakni dimensi akuisisi pengetahuan sebanyak 3 item (AKU1-AKU3), dimensi diseminasi pengetahuan sebanyak 5 item (DIS1-DIS5), dimensi aplikasi pengetahuan sebanyak 4 item (APL1-APL4).

Teknik statistik paling populer di bawah Structural Equation Model SEM adalah berbasis kovarian pendekatan (CB-SEM) dan teknik kuadrat terkecil parsial berbasis varian (PLS-SEM) (Sarstedt et al., 2014). Namun, PLS-SEM akhir-akhir ini mendapat perhatian yang luas di banyak orang disiplin ilmu seperti pemasaran, manajemen strategis, sistem informasi manajemen, dan cabang keilmuan lainnya (Hair et al., 2012). Kemampuan PLS-SEM untuk menangani permasalahan problematic modelling yang biasa terjadi di lingkungan social ilmu pengetahuan seperti karakteristik data yang tidak biasa (misalnya data non-normal) dan model yang sangat kompleks adalah alasan penting di balik peningkatan penggunaan pendekatan ini. Mengingat keuntungan dari pendekatan ini, penelitian ini menggunakan PLS-SEM untuk menguji secara keseluruhan dari hipotesis yang diajukan. Perangkat lunak SmartPLS dilakukan untuk mengevaluasi masingmasing outer model dan inner model.. Pengujian outer model dilakukan untuk memastikan keandalan dan validitas pengukuran, sedangkan hipotesis yang diperkenalkan diperiksa melalui inner model.

Tabel 1. Daftar Item Penelitian

\begin{tabular}{|c|c|c|}
\hline Notasi & Item & Referensi \\
\hline \multicolumn{2}{|c|}{ Kepemimpinan Transformasional (KEP) } & Bogler (2001) \\
\hline KOL1 & Pimpinan memproyeksikan dirinya sebagai panutan. & \\
\hline KOL2 & $\begin{array}{l}\text { Pimpinan menunjukkan bakat dan kemampuannya dalam } \\
\text { pengambilan keputusan. }\end{array}$ & \\
\hline KOL3 & $\begin{array}{l}\text { Pimpinan berusaha mencapai tujuan kolektif untuk memenuhi misi } \\
\text { bersama. }\end{array}$ & \\
\hline KOL4 & Pimpinan menyajikan tantangan dan proyek baru. & \\
\hline KOL5 & $\begin{array}{l}\text { Pimpinan percaya pada kemampuan anggota timnya untuk } \\
\text { menghadapi tantangan/hambatan pekerjaan. }\end{array}$ & \\
\hline \multicolumn{2}{|c|}{ Akuisisi Pengetahuan (AKU) } & Darroch (2003) \\
\hline AKP1 & $\begin{array}{l}\text { Perusahaan kami memiliki proses untuk menghasilkan } \\
\text { pengetahuan baru dari pengetahuan yang sudah ada }\end{array}$ & \\
\hline AKP2 & $\begin{array}{l}\text { Perusahaan kami memiliki proses untuk memperoleh pengetahuan } \\
\text { tentang produk baru } \\
\text { dalam industri kami }\end{array}$ & \\
\hline AKP3 & $\begin{array}{l}\text { Perusahaan kami memberikan penghargaan kepada karyawannya } \\
\text { yang menyajikan informasi dan pengetahuan baru }\end{array}$ & \\
\hline \multicolumn{2}{|c|}{ Diseminasi Pengetahuan (DIS) } & Darroch (2003) \\
\hline DSP1 & $\begin{array}{l}\text { Perusahaan kami memiliki mekanisme untuk penyaringan, } \\
\text { pencatatan silang dan integrasi sumber dan jenis pengetahuan yang } \\
\text { berbeda }\end{array}$ & \\
\hline DSP2 & $\begin{array}{l}\text { Perusahaan kami menggunakan database, repositori dan aplikasi } \\
\text { teknologi informasi untuk menyimpan pengetahuan agar mudah } \\
\text { diakses oleh semua karyawan }\end{array}$ & \\
\hline DSP3 & $\begin{array}{l}\text { Dalam perusahaan kami, informasi tentang pasar didistribusikan } \\
\text { secara bebas }\end{array}$ & \\
\hline DSP4 & $\begin{array}{l}\text { Perusahaan kami mengirimkan laporan tepat waktu dengan } \\
\text { informasi yang sesuai ke departemen fungsional }\end{array}$ & \\
\hline DSP5 & Perusahaan kami memiliki banyak informasi terdokumentasi & \\
\hline
\end{tabular}


4572 Membangun Inovasi Organisasi: Antara Kepemimpinan Transformasional dan Proses Manajemen Pengetahuan - Dhaniel Hutagalung, Dewiana Novitasari, Nelson Silitonga, Masduki Asbari, Nana Supiana DOI: https://doi.org/10.31004/edukatif.v3i6.1522

\begin{tabular}{|c|c|c|}
\hline \multicolumn{3}{|c|}{ tentang keberhasilan dan kegagalan pengembangan produk } \\
\hline \multicolumn{2}{|c|}{ Aplikasi Pengetahuan (APL) } & \multirow[t]{2}{*}{ Darroch (2003) } \\
\hline APP1 & Perusahaan kami merespon dengan cepat kebutuhan pelanggan & \\
\hline APP2 & \multicolumn{2}{|l|}{ Perusahaan kami menanggapi dengan cepat perubahan teknologi } \\
\hline APP3 & \multicolumn{2}{|l|}{$\begin{array}{l}\text { Perusahaan kami menanggapi dengan cepat setiap tindakan } \\
\text { pesaing }\end{array}$} \\
\hline APP4 & \multicolumn{2}{|l|}{$\begin{array}{l}\text { Perusahaan kami fleksibel dan realistis dalam mengubah produk, } \\
\text { proses dan strategi kami }\end{array}$} \\
\hline \multicolumn{2}{|c|}{ Kinerja Inovasi (KIN) } & \multirow{4}{*}{$\begin{array}{l}\text { Cavusgil et al. } \\
\text { (2003) dan Prajogo } \\
\& \text { Hong (2008), serta } \\
\text { telah divalidasi oleh } \\
\text { (Yusr et al., 2017) }\end{array}$} \\
\hline KIN1 & $\begin{array}{l}\text { Jumlah perkenalan produk baru kami cukup tinggi dibandingkan } \\
\text { dengan pesaing lain }\end{array}$ & \\
\hline KIN2 & $\begin{array}{l}\text { Dibandingkan kompetitor lain, perusahaan kami lebih cepat dalam } \\
\text { menghadirkan produk yang baru ke pasar }\end{array}$ & \\
\hline KIN3 & $\begin{array}{l}\text { Perusahaan kami mendorong ide-ide baru yang dihadirkan untuk } \\
\text { mengembangkan kinerja }\end{array}$ & \\
\hline KIN4 & $\begin{array}{l}\text { Perkenalan produk baru kami telah meningkat selama } 5 \text { tahun } \\
\text { terakhir }\end{array}$ & \\
\hline KIN5 & $\begin{array}{l}\text { Perusahaan kami mengubah metode produksi dengan kecepatan } \\
\text { tinggi dibandingkan dengan yang lain pesaing }\end{array}$ & \\
\hline KIN6 & Daya saing teknologi perusahaan kami tinggi & \\
\hline KIN7 & $\begin{array}{l}\text { Selama lima tahun terakhir, perusahaan kami telah } \\
\text { mengembangkan banyak pendekatan manajemen baru }\end{array}$ & \\
\hline
\end{tabular}

Sejalan dengan pembahasan di atas, penelitian ini mengusulkan hipotesis utama berikut: Proses manajemen pengetahuan berpengaruh signifikan terhadap kinerja inovasi. Dengan pengembangan sub-hipotesis sebagai berikut:

H1: Kepemimpinan transformasional berpengaruh signifikan terhadap proses akuisisi pengetahuan.

H2: Kepemimpinan transformasional berpengaruh signifikan terhadap proses diseminasi pengetahuan.

H3: Kepemimpinan transformasional berpengaruh signifikan terhadap proses aplikasi pengetahuan.

H4: Kepemimpinan transformasional berpengaruh signifikan terhadap kinerja inovasi.

H5: Proses akuisisi pengetahuan berpengaruh signifikan terhadap kinerja inovasi.

H6: Proses diseminasi pengetahuan berpengaruh signifikan terhadap kinerja inovasi.

H7: Proses aplikasi pengetahuan berpengaruh signifikan terhadap kinerja inovasi.

Berdasarkan pembahasan sebelumnya, kerangka teoritis diperkenalkan seperti yang ditunjukkan pada Gambar 1 di bawah ini. 


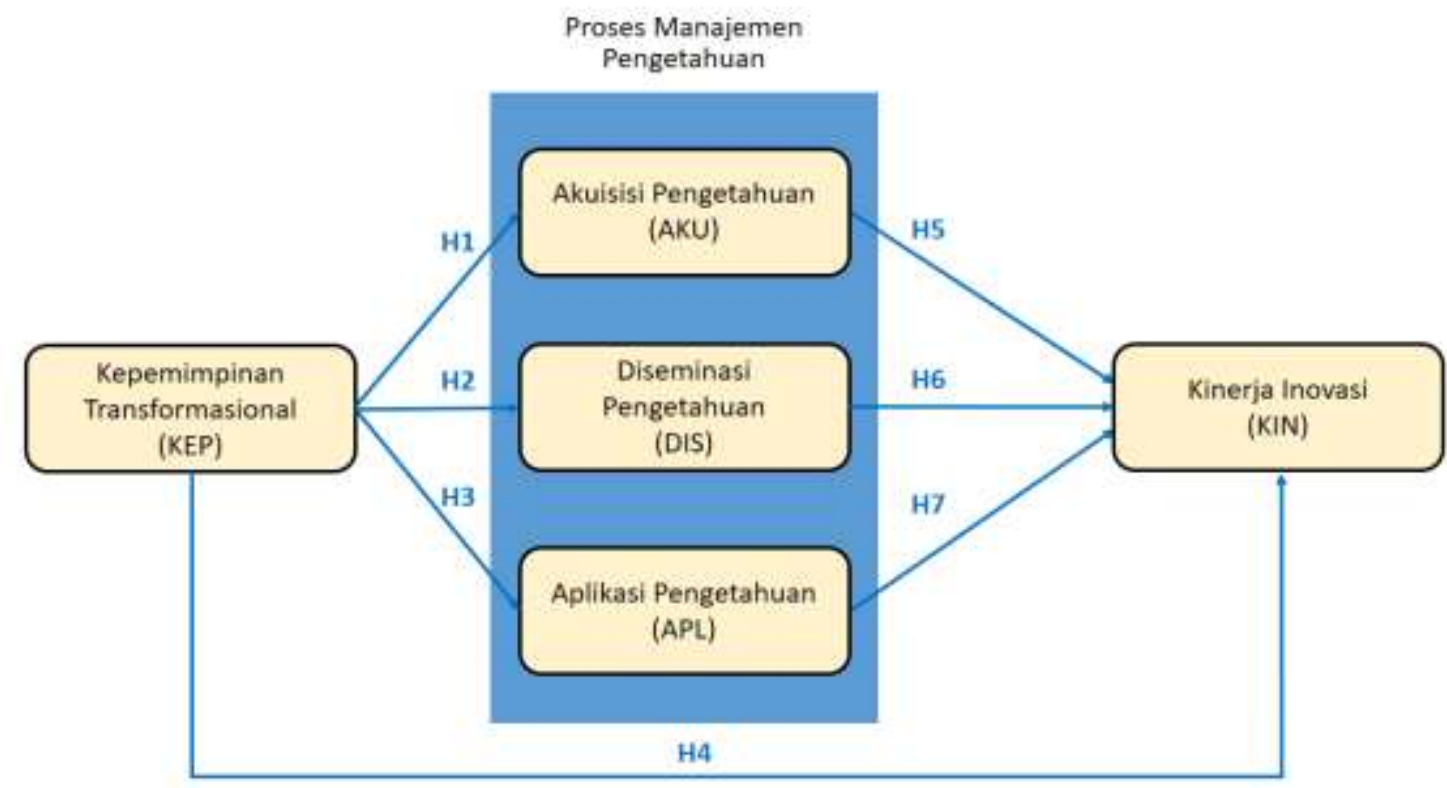

Gambar 1. Model Konseptual Penelitian

\section{HASIL DAN PEMBAHASAN}

\section{Hasil}

Total ada 117 karyawan yang berpartisipasi. Terbanyak adalah laki-laki (68.4\%), kemudian wanita (31.6\%). Mereka memiliki kelompok umur yang berbeda-beda, di bawah 30 tahun (24.8\%), berkisar antara 30-40 tahun (47.0\%), dan lebih dari 40 tahun (28.2\%). Masa kerja karyawan sebagian di antaranya di bawah 5 tahun (35.9\%), antara 5-10 tahun (47.9\%), dan lebih dari 10 tahun (16.2\%). Pendidikan mayoritas diploma/sarjana (94.0\%) kemudian SMA/SMK (6.0\%).

Table 2. Deskripsi Sampel

\begin{tabular}{|c|c|c|c|}
\hline \multicolumn{2}{|c|}{ Kriteria } & \multirow{2}{*}{$\begin{array}{c}\text { Jumlah } \\
80 \\
\end{array}$} & \multirow{2}{*}{$\begin{array}{c}\% \\
68.4 \% \\
\end{array}$} \\
\hline Jenis Kelamin & Laki-laki & & \\
\hline & Wanita & 37 & $31.6 \%$ \\
\hline \multirow[t]{3}{*}{ Usia (per Maret 2021) } & $<30$ tahun & 29 & $24.8 \%$ \\
\hline & $30-40$ tahun & 55 & $47.0 \%$ \\
\hline & $>40$ tahun & 33 & $28.2 \%$ \\
\hline \multirow[t]{3}{*}{ Masa kerja sebagai karyawan } & $<5$ tahun & 42 & $35.9 \%$ \\
\hline & 5-10 tahun & 56 & $47.9 \%$ \\
\hline & $>10$ tahun & 19 & $16.2 \%$ \\
\hline \multirow[t]{2}{*}{ Ijazah tertinggi } & Diploma/Sarjana & 110 & $94.0 \%$ \\
\hline & SMA/SMK & 7 & $6.0 \%$ \\
\hline
\end{tabular}

Tahap pengujian model pengukuran meliputi pengujian validitas konvergen, validitas diskriminan. Sementara untuk menguji reliabilitas konstruk digunakan nilai cronbach's alpha dan composite reliability. Hasil analisis PLS dapat digunakan untuk menguji hipotesis penelitian jika seluruh indikator dalam model PLS telah memenuhi syarat validitas konvergen, validitas deskriminan dan uji reliabilitas. 
Uji validitas konvergen dilakukan dengan melihat nilai loading factor masing-masing indikator terhadap konstruknya. Pada sebagian besar referensi, bobot faktor sebesar 0.5 atau lebih dianggap memiliki validasi yang cukup kuat untuk menjelaskan konstruk laten (Chin, 1998; Ghozali, 2014; Hair et al., 2010). Pada penelitian ini batas minimal besarnya loading factor yang diterima adalah 0.7 , dan dengan syarat nilai AVE setiap konstruk > 0.5 (Ghozali, 2014). Setelah melalui pengolahan SmartPLS 3.0, seluruh indikator atau item penelitian telah memiliki nilai loading factor di atas 0.7 dan nilai AVE di atas 0.5. Model fit atau valid dari penelitian ini bias dilihat pada Gambar 2. Jadi dengan demikian, validitas konvergen dari model penelitian ini sudah memenuhi syarat. Nilai loadings, cronbach's alpha, composite reliability dan AVE setiap konstruk selengkapnya dapat dilihat Gambar 2 dan Tabel 3.

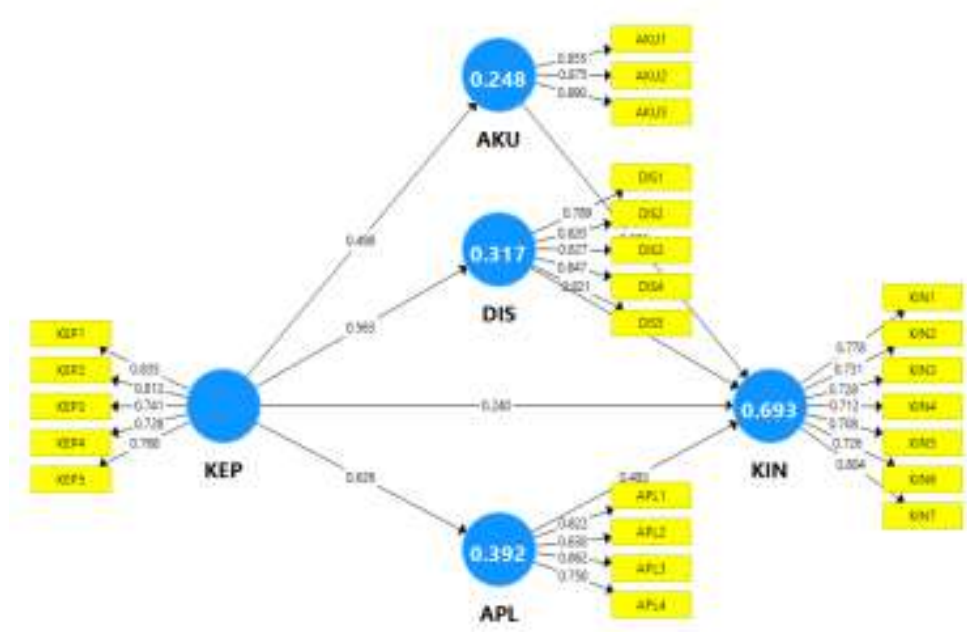

Gambar 2. Model Penelitian Valid

Sumber: Hasil pengolahan data oleh SmartPLS 3.0 (2021)

Tabel 3. Items Loadings, Cronbach's Alpha, Composite Reliability, and Average Variance Extracted (AVE)

\begin{tabular}{llllll}
\hline Varables & Items & Loadings & $\begin{array}{l}\text { Cronbach's } \\
\text { Alpha }\end{array}$ & $\begin{array}{l}\text { Composite } \\
\text { Reliability }\end{array}$ & AVE \\
\hline $\begin{array}{l}\text { Kepemimpinan Transformasional } \\
\text { (KEP) }\end{array}$ & KEP1 & 0.835 & 0.836 & 0.884 & 0.605 \\
& & & & & \\
\hline & KEP2 & 0.812 & & & \\
\hline & KEP3 & 0.741 & & & \\
\hline & KEP4 & 0.728 & & & \\
\hline & KEP5 & 0.768 & & 0.906 & \\
\hline Akuisisi Pengetahuan (AKU) & AKU1 & 0.855 & 0.845 & & \\
& AKU2 & 0.875 & & & \\
\hline & AKU3 & 0.890 & & & \\
\hline Diseminasi Pengetahuan (DIS) & DIS1 & 0.789 & 0.880 & 0.912 & \\
\cline { 2 - 6 } & DIS2 & 0.820 & & & \\
\hline & DIS3 & 0.827 & & & \\
\hline & DIS4 & 0.847 & & & \\
\hline & DIS5 & 0.821 & & & \\
\hline Aplikasi Pengetahuan (APL) & APL1 & 0.822 & 0.833 & & \\
\hline & APL2 & 0.830 & & & \\
\hline & APL3 & 0.862 & & & \\
\hline
\end{tabular}


4575 Membangun Inovasi Organisasi: Antara Kepemimpinan Transformasional dan Proses Manajemen Pengetahuan - Dhaniel Hutagalung, Dewiana Novitasari, Nelson Silitonga, Masduki Asbari, Nana Supiana DOI: https://doi.org/10.31004/edukatif.v3i6.1522

\begin{tabular}{rrrrrr}
\hline Kinerja Inovasi (KIN) & KIN1 & 0.778 & 0.863 & 0.895 & 0.550 \\
\hline KIN2 & 0.731 & & & \\
\hline KIN3 & 0.728 & & \\
\hline KIN4 & 0.712 & & \\
\hline KIN5 & 0.708 & & \\
\hline KIN6 & 0.726 & & \\
\hline KIN7 & 0.804 & & \\
\hline
\end{tabular}

Tabel 4. Discriminant Validity

\begin{tabular}{|c|c|c|c|c|c|}
\hline Variabel & $\mathbf{A K U}$ & APL & DIS & KEP & KIN \\
\hline Akuisisi Pengetahuan (AKU) & 0.874 & & & & \\
\hline Aplikasi Pengetahuan (APL) & 0.642 & 0.817 & & & \\
\hline Diseminasi Pengetahuan (DIS) & 0.799 & 0.767 & 0.821 & & \\
\hline $\begin{array}{l}\text { Kepemimpinan transformasional } \\
\text { (KEP) }\end{array}$ & 0.498 & 0.626 & 0.563 & 0.778 & \\
\hline Kinerja Inovasi (KIN) & 0.622 & 0.795 & 0.708 & 0.662 & 0.741 \\
\hline
\end{tabular}

Tabel 5. Collinearity Statistics (VIF)

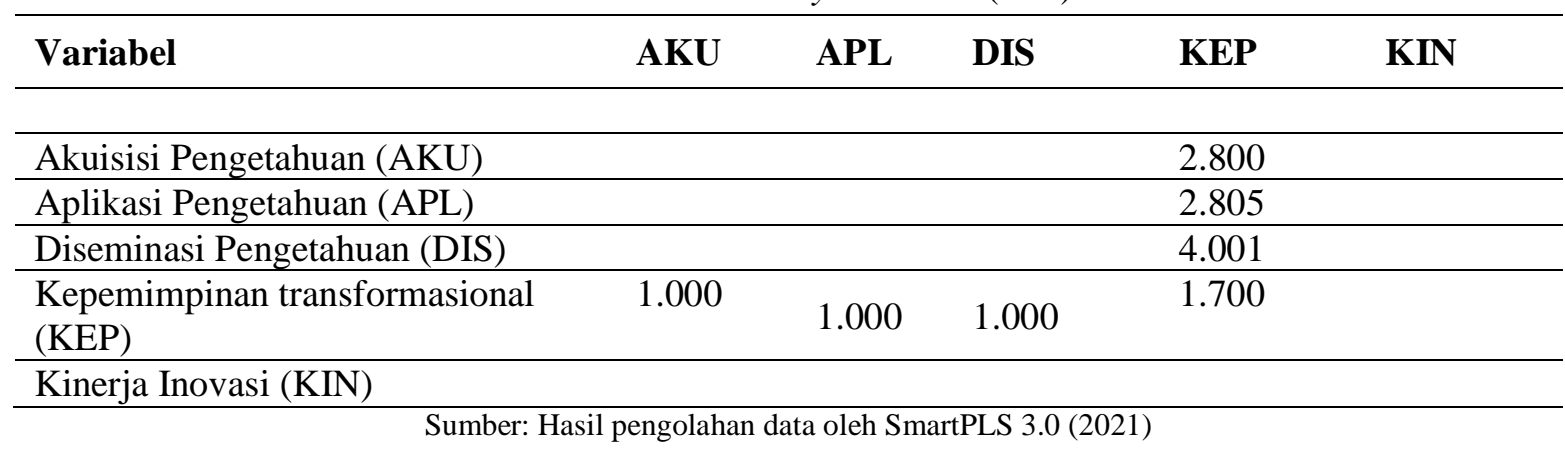

Discriminant validity dilakukan untuk memastikan bahwa setiap konsep dari masing-masing variabel laten berbeda dengan variabel laten lainnya. Model mempunyai discriminant validity yang baik jika nilai kuadrat AVE masing-masing konstruk eksogen (nilai pada diagonal) melebihi korelasi antara konstruk tersebut dengan konstruk lainnya (nilai di bawah diagonal) (Ghozali, 2014) . Hasil pengujian discriminant validity adalah dengan menggunakan nilai kuadrat AVE, yakni dengan melihat Fornell-Larcker Criterion Value diperoleh sebagaimana ditunjukkan pada Tabel 4. Hasil uji validitas deskriminan pada tabel 3 di atas menunjukkan bahwa seluruh konstruk telah memiliki nilai akar kuadrat AVE di atas nilai korelasi dengan konstruk laten lainnya (melalui kriteria Fornell-Larcker). Demikian juga nilai cross-loading seluruh item dari suatu indikator lebih besar dari item indikator lainnya sebagaimana disebut pada Tabel 4, sehingga dapat disimpulkan bahwa model telah memenuhi validitas deskriminan (Fornell \& Larcker, 1981). Selanjutnya, evaluasi kolinearitas dilakukan untuk mengetahui apakah ada kolinearitas dalam model. Untuk menemukan collinearity, diperlukan penghitungan VIF dari setiap konstruk. Jika skor VIF lebih tinggi dari 5, maka model tersebut memiliki collinearity (Hair et al., 2014). Sebagaimana ditunjukkan pada Tabel 5, semua skor VIF lebih kecil dari 5, artinya bahwa model ini tidak memiliki masalah collinearity (Purwanto et al., 2019; Purwanto, Asbari, Santoso, Paramarta, et al., 2020; Purwanto, Asbari, \& Santoso, 2021b, 2021a; Purwanto, Asbari, Santoso, et al., 2021). 
Reliabilitas konstruk dapat dinilai dari nilai cronbach's alpha dan composite reliability dari masingmasing konstruk. Nilai composite reliability dan cronbach's alpha yang disarankan adalah lebih dari 0.7 (Ghozali, 2014). Hasil uji reliabilitas pada tabel 2 di atas menunjukkan bahwa seluruh konstruk telah memiliki nilai composite reliability dan cronbach's alpha lebih besar dari 0.7 (>0.7). Kesimpulannya, seluruh konstruk telah memenuhi reliabilitas yang dipersyaratkan.

Pengujian hipotesis dalam PLS disebut juga sebagai uji inner model. Uji ini meliputi uji signifikansi pengaruh langsung dan tidak langsung serta pengukuran besarnya pengaruh variabel eksogen terhadap variabel endogen. Untuk mengetahui pengaruh kepemimpinan transformasional terhadap proses manajemen pengetahuan dan kinerja inovasi organisasi dibutuhkan uji pengaruh langsung. Uji pengaruh dilakukan dengan menggunakan uji t-statistik dalam model analisis partial least squared (PLS) dengan menggunakan bantuan software SmartPLS 3.0. Dengan teknik boothstrapping, diperoleh nilai $R$ Square dan nilai uji signifikansi sebagaimana Tabel 6 dan Tabel 7 di bawah ini:

Tabel 6. Nilai $R$ Square

\begin{tabular}{lcc}
\hline & R Square & R Square Adjusted \\
\hline Akuisisi Pengetahuan (AKU) & 0.248 & 0.243 \\
\hline Aplikasi Pengetahuan (APL) & 0.392 & 0.388 \\
\hline Diseminasi Pengetahuan (DIS) & 0.317 & 0.313 \\
\hline Kinerja Inovasi (KIN) & 0.693 & 0.686 \\
\hline & & \\
\hline
\end{tabular}

Sumber: Hasil pengolahan data oleh SmartPLS 3.0 (2021)

Tabel 7. Hypotheses Testing

\begin{tabular}{llccccl}
\hline Hypotheses & Relationship & Beta & SE & T Statistics & P-Values & Decision \\
\hline H1 & KEP -> AKU & 0.498 & 0.058 & 8.630 & 0.000 & Didukung \\
\hline H2 & KEP -> DIS & 0.563 & 0.051 & 11.091 & 0.000 & Didukung \\
\hline H3 & KEP -> APL & 0.626 & 0.045 & 13.930 & 0.000 & Didukung \\
\hline H4 & KEP -> KIN & 0.240 & 0.056 & 4.286 & 0.000 & Didukung \\
\hline H5 & AKU -> KIN & 0.085 & 0.093 & 0.916 & 0.360 & Tidak Didukung \\
\hline H6 & DIS -> KIN & 0.126 & 0.099 & 1.280 & 0.201 & Tidak Didukung \\
\hline H7 & APL -> KIN & 0.493 & 0.070 & 7.052 & 0.000 & Didukung
\end{tabular}

Sumber: Hasil pengolahan data oleh SmartPLS 3.0 (2021)

Berdasarkan Tabel 6 di atas, nilai $R$ Square akuisisi pengetahuan (AKU) sebesar 0.248 yang berarti bahwa variabel kepemimpinan transformasional (KEP) sebesar $24.8 \%$, sedangkan sisanya sebesar $75.2 \%$ dijelaskan oleh variabel lain yang tidak dibahas dalam penelitian ini. Nilai $R$ Square diseminasi pengetahuan (DIS) sebesar 0.317 yang berarti bahwa variable kepemimpinan transformasional (KEP) sebesar 31.7\%, sedangkan sisanya sebesar $68.3 \%$ dijelaskan oleh variabel lain yang tidak dibahas dalam penelitian ini. Nilai $R$ Square aplikasi pengetahuan (APL) 0.392 yang berarti bahwa variable kepemimpinan transformasional (KEP) sebesar $39.2 \%$, sedangkan sisanya sebesar $60.8 \%$ dijelaskan oleh variabel lain yang tidak dibahas dalam penelitian ini. Nilai $R$ Square kinerja inovasi (KIN) sebesar 0.693 yang berarti bahwa variable kinerja inovasi (KIN) mampu dijelaskan oleh variabel proses manajemen pengetahuan dengan ketiga dimensi yang diukur, 
4577 Membangun Inovasi Organisasi: Antara Kepemimpinan Transformasional dan Proses Manajemen Pengetahuan - Dhaniel Hutagalung, Dewiana Novitasari, Nelson Silitonga, Masduki Asbari, Nana Supiana DOI: https://doi.org/10.31004/edukatif.v3i6.1522

yakni akuisisi pengetahuan (AKU), diseminasi pengetahuan (DIS), dan aplikasi pengetahuan (APL) sebesar $69.3 \%$, sedangkan sisanya sebesar $30.7 \%$ dijelaskan oleh variabel lain yang tidak dibahas dalam penelitian ini. Sedangkan Tabel 7 menampilkan t-statistics dan p-values yang menunjukkan pengaruh antar variable penelitian yang telah disebutkan.

\section{Pembahasan}

Berdasarkan tinjauan komprehensif dari literatur yang relevan, penelitian ini mengusulkan model struktural hubungan di antara sejumlah domain berbeda di dunia bisnis saat ini, yaitu kepemimpinan transformasional, proses manajemen pengetahuan dan kinerja inovasi. Intinya, studi ini berhasil untuk menyelidiki dan memperjelas peran kepemimpinan transformasional dan proses manajemen pengetahuan dalam meningkatkan inovasi kinerja. Persepsi karyawan perusahaan manufaktur di Tangerang Indonesia menjadi sumber informasi telah berhasil menguji hipotesis dan model yang digunakan dalam penelitian. Hasil penelitian ini memberikan sebuah bukti empiris bahwa kepemimpinan transformasional memberi pengaruh positif dan signifikan terhadap proses manajemen pengetahuan. Dari perspektif teoritis, hasil penelitian ini memberikan bukti empiris tentang peran positif proses manajemen pengetahuan sebagai proses yang berpengaruh untuk meningkatkan kinerja inovasi perusahaan manufaktur. Di sisi lain, dari perspektif manajerial, hasil penelitian ini memberikan gambaran pengambil keputusan di perusahaan manufaktur dengan pemahaman yang lebih baik tentang bagaimana praktik kepemimpinan transformasional dan proses manajemen pengetahuan yang mempengaruhi kinerja inovsi organisasi. Berdasarkan temuan logis dan masuk akal ini, manajer harus fokus pada pembentukan sistem di mana pengetahuan yang diperoleh dapat diakses dan diterapkan oleh departemen yang berbeda untuk meningkatkan kinerja inovasi. Studi ini menemukan fakta bahwa dimensi akuisisi dan diseminasi pengetahuan tidak berpengaruh signifikan terhadap kinerja inovasi, dan hanya aplikasi pengetahuan yang berpengaruh signifikan terhadap kinerja inovasi organisasi. Artinya, kepemilikan pengetahuan dan knowledge sharing yang dimiliki dan dilakukan oleh karyawan tidak berdampak pada inovasi jika pengetahuan tersebut tidak diaplikasikan dalam proses pekerjaan. Temuan studi ini agak berbeda dengan temuan Darroch (2005) yang menganggap pengetahuan manajemen sebagai proses yang diperlukan untuk mencapai kinerja inovasi yang diinginkan. Studi ini juga menemukan fakta bahwa paling besar pengaruh kepemimpinan transformasional adalah pada dimensi aplikasi pengetahuan, disusul pada akuisisi dan diseminasi pengetahuan. Menurut Wiratna (2014), hasil studi ini menunjukkan bahwa pengaruh kepemimpinan transformasional terhadap ketiga dimensi proses manajemen pengetahuan dalam level kuat dan sangat kuat.

Tidak diragukan lagi bahwa penelitian kali ini memiliki beberapa keterbatasan yang perlu disoroti. Pertama, penelitian ini memiliki hanya memeriksa hubungan langsung antara variabel yang diselidiki yaitu, kepemimpinan transformasional, proses manajemen pengetahuan dan kinerja inovasi. Oleh karena itu, disarankan untuk memperpanjang penelitian ini dengan menyelidiki hubungan interaksi antara semua variabel lain yang relevan, semisal hubungan pengaruh variabel knowledge sharing, motivasi personal, OCB, dan seterusnya. Itu juga disarankan untuk memeriksa peran moderasi atau mediasi dari variabel terkait lainnya, seperti organizational citizenship behavior untuk memberikan gambaran lebih lanjut tentang masalah ini. Juga disarankan untuk menyelidiki hubungan antara proses manajemen pengetahuan dan aspek inovasi yang berbeda daripada menguji inovasi kinerja secara umum, yang akan membantu memperluas pemahaman kita tentang hubungan ini.

Mengingat studi ini fokus model relationship antara kepemimpinan transformasional, proses manajemen pengetahuan dan kinerja inovasi, untuk penelitian di masa depan, penulis merekomendasikan untuk mengakomodasi lebih banyak prediktor dan membandingkan kemampuan penjelasan mereka dengan yang dinilai dalam penelitian ini. Penelitian berikutnya juga dapat mencoba untuk memperbaiki kekurangan studi ini dengan memasukkan lebih banyak variabel kontrol (misalnya, perbedaan anggota dalam jenis 
4578 Membangun Inovasi Organisasi: Antara Kepemimpinan Transformasional dan Proses Manajemen Pengetahuan - Dhaniel Hutagalung, Dewiana Novitasari, Nelson Silitonga, Masduki Asbari, Nana Supiana DOI: https://doi.org/10.31004/edukatif.v3i6.1522

kelamin, ragam generasi $\mathrm{X}, \mathrm{Y}, \mathrm{Z}$, dan seterusnya), bisa juga dengan mensurvei lebih banyak anggota tim di berbagai industri dan budaya yang berbeda.

Alhasil, studi ini mengkonfirmasi model hubungan mediasi, yakni mediasi proses manajemen pengetahuan atas hubungan pengaruh kepemimpinan transformasional terhadap kinerja inovasi organisasi. Novelty studi ini berhasil mengelaborasi dimensi proses manajemen pengetahuan yang selama ini masih sangat jarang dieksplorasi dalam penelitian-penelitian, apalagi penelitian pada unit analisis industri manufaktur di Indonesia.

\section{KESIMPULAN}

Kinerja inovasi tampaknya menjadi salah satu indikator penting untuk meraih keberhasilan organisasi yang berkelanjutan. Dalam hal ini, praktik kepemimpinan untuk mendorong mendapatkan, mengelola dan mengaplikasikan pengetahuan di dalam praktik kerja diakui sebagai salah satu persyaratan penting untuk memperkuat inovasi kinerja. Oleh karena itu, tujuan utama dari penelitian ini adalah untuk mengetahui secara empiris tentang pengaruh kepemimpinan transformasional terhadap proses manajemen pengetahuan, serta pengaruh proses manajemen pengetahuan terhadap kinerja inovasi di industri manufaktur, dalam perspektif karyawan. Temuan studi ini menekankan bahwa kemampuan organisasi dalam menjalankan praktik kepemimpinan transformasional sangat berpengaruh untuk memperoleh pengetahuan dan memanfaatkannya, sebagai penentu utama kinerja inovasi. Oleh karena itu, temuan studi ini merekomendasikan praktik kepemimpinan transformasional yang efektif guna meningkatkan dan mempercepat proses manajemen pengetahuan dan juga meningkatkan kinerja inovasi organisasi. Kesimpulan yang diperoleh ini memiliki konsekuensi yang signifikan terhadap kebijakan manajemen perusahaan manufaktur di Indonesia.

\section{DAFTAR PUSTAKA}

Agistiawati, E., \& Asbari, M. (2020). Pengaruh Persepsi Siswa Atas Lingkungan Belajar Dan Penguasaan Kosa Kata Terhadap Kemampuan Berbicara Bahasa Inggris Siswa Sekolah Menengah Atas Swasta Balaraja. Edupsycouns: Journal Of Education, Psychology And Counseling, 2(1), 513-523.

Aman, M., \& Asbari, M. (2020). Pengembangan Aplikasi History Gps Tracker Berbasis Web Pada Handphone. Jikem: Jurnal Ilmu Komputer, Ekonomi Dan Manajemen, 1(1), 17-29.

Aminbeidokhti, A., Nikabadi, M. S., \& Hoseini, A. M. (2016). The Role Of Transformational Leadership And Knowledge Management Processes On The Rate Of Organisational Innovation. International Journal Of Knowledge Management Studies, 7(3-4), 270-287.

Amri, W. A. A., Asbari, M., Gazali, Novitasari, D., \& Purwanto, A. (2021). The Effect Of Religiosity And Service Quality On Job Satisfaction: A Case Study Of Msme Employees. International Journal Of Social And Management Studies (Ijosmas), 01(01), 53-63. Https://Doi.Org/Https://Doi.Org/10.5555//josmas.V2i1.7

Anggraeni, A., Hasna, S., Novitasari, D., \& Asbari, M. (2020). Pengaruh Pelatihan Kerja Dan Motivasi Kerja Terhadap Prestasi Karyawan Pada Pt. Agrindo Maju Lestari. Jubisma, 2(1), 1-18. Http://Jubisma.Ipem.Ac.Id/Index.Php/Jubisma/Article/View/32

Asbari, M. (2011). Kepemimpinan Transformasional: Landasan Menuju World Class Company.

Asbari, M. (2018). Ayah Tanpa Wajah. Penerbit Tosca.

Asbari, M. (2019). Pengaruh Kepemimpinan Transformasional Dan Iklim Organisasi Terhadap Kinerja Dosen. Joce Ip, 13(2), 172-186. Http://Jurnal.Ipem.Ac.Id/Index.Php/Joce-Ip/Article/View/187

Asbari, M. (2020). Is Transformational Leadership Suitable For Future Organizational Needs? International 
4579 Membangun Inovasi Organisasi: Antara Kepemimpinan Transformasional dan Proses Manajemen Pengetahuan - Dhaniel Hutagalung, Dewiana Novitasari, Nelson Silitonga, Masduki Asbari, Nana Supiana DOI: https://doi.org/10.31004/edukatif.v3i6.1522

Journal Of Sociology, Policy And Law (Ijospl), $01(01), \quad 51-55$. Https://Ijospl.Org/Index.Php/Ijospl/Article/View/17

Asbari, M., \& Novitasari, D. (2020a). Pengaruh Aktivitas Berbagi Pengetahuan Dan Mediasi Budaya Terhadap Kemampuan Inovasi Guru. Jurnal Manajemen Dan Supervisi Pendidikan, 5(1), 324-334. Http://Journal2.Um.Ac.Id/Index.Php/Jmsp/Article/View/15253

Asbari, M., \& Novitasari, D. (2020b). The Role Of Readiness For Change On Part-Timer Employee Performance: Analysis Of Transformational Leadership Practice In Convection Industry. Journal Of Communication Education (Joce), 14(02). Http://Jurnal.Ipem.Ac.Id/Index.Php/Joce-Ip/Article/View/220

Asbari, M., Novitasari, D., Gazali, G., Silitonga, N., \& Pebrina, E. T. (2020). Analisis Kesiapan Untuk Berubah Di Masa Pandemi Covid-19: Studi Pengaruh Kepemimpinan Transformasional Terhadap $\begin{array}{lllll}\text { Kinerja Karyawan. } & \text { Jurnal }\end{array}$ Https://Ejournal.Bsi.Ac.Id/Ejurnal/Index.Php/Perspektif/Article/View/8576

Asbari, M., Novitasari, D., \& Pebrina, E. T. (2021). Pengaruh Mediasi Mental Kesiapan Untuk Berubah Dan Work-Family Conflict Terhadap Kinerja Karyawan Di Masa Pandemi Covid-19. Mega Aktiva: Jurnal Ekonomi Dan Manajemen, 10(1), 24-38. Https://Megaaktiva.Umkendari.Ac.Id/Index.Php/Jurnal/Article/View/123

Asbari, M., Nurhayati, W., \& Purwanto, A. (2019). The Effect Of Parenting Style And Genetic Personality On Children Character Development. Jurnal Penelitian Dan Evaluasi Pendidikan, 23(2), 206-218. Https://Doi.Org/10.21831/Pep.V23i2.28151

Asbari, M., Purba, J. T., Hariandja, E. S., \& Sudibjo, N. (2021). Membangun Kesiapan Berubah Dan Kinerja Karyawan: Kepemimpinan Transformasional Versus Transaksional. Jurnal Ilmiah Manajemen Dan Bisnis, 22(1).

Asbari, M., Purwanto, A., Fayzhall, M., Goestjahjanti, F. S., Winanti, W., Yuwono, T., Hutagalung, D. D., Basuki, S., Maesaroh, S., \& Mustofa, M. (2020). Peran Kepemimpinan Transformasional Dan Organisasi Pembelajaran Terhadap Kapasitas Inovasi Sekolah. Edupsycouns: Journal Of Education, Psychology And Counseling, 2(1), 122-145.

Asbari, M., Santoso, P. B., \& Prasetya, A. B. (2020). Elitical And Antidemocratic Transformational Leadership Critics: Is It Still Relevant? (A Literature Study). International Journal Of Sociology, Policy And Law (Ijospl), 01(01), 11-16. Https://Doi.Org/Https://Doi.Org/10.8888/Ijospl.V1i1.10

Bass, B. M., \& Riggio, R. E. (2006). Transformational Leadership. In Lawrence Erlbaum Associates, Inc., Publishers (2nd Ed.). Https://Doi.Org/10.5742/Mewfm.2017.92984

Basuki, S., Novitasari, D., Fahlevi, M., Nadeak, M., Fahmi, K., Pebrina, E. T., Sudiyono, R. N., \& Asbari, M. (2020). Performance Analysis Of Female Employees In The Covid-19 Pandemic Period: The Effects Of Readiness For Change And Effectiveness Of Transformational Leadership. Solid State Technology, 63(1s), 201-217. Http://Www.Solidstatetechnology.Us/Index.Php/Jsst/Article/View/709

Bogler, R. (2001). The Influence Of Leadership Style On Teacher Job Satisfaction. Educational Administration Quarterly, 37(5), 662-683. Https://Doi.Org/10.1177/00131610121969460

Cavusgil, S. T., Calantone, R. J., \& Zhao, Y. (2003). Tacit Knowledge Transfer And Firm Innovation Capability. Journal Of Business \& Industrial Marketing.

Chin, W. (1998). The Partial Least Squares Approach To Structural Equation Modeling (E. Modern Methods For Business Research, In: G. A. Marcoulides (Ed.)). Lawrence Erlbaum Associates Publisher.

Creswell, J. W., \& Creswell, J. D. (2017). Research Design: Qualitative, Quantitative, And Mixed Methods Approaches. Sage Publications.

Darroch, J. (2003). Developing A Measure Of Knowledge Management Behaviors And Practices. Journal Of Knowledge Management.

Darroch, J. (2005). Knowledge Management, Innovation And Firm Performance. Journal Of Knowledge 
4580 Membangun Inovasi Organisasi: Antara Kepemimpinan Transformasional dan Proses Manajemen Pengetahuan - Dhaniel Hutagalung, Dewiana Novitasari, Nelson Silitonga, Masduki Asbari, Nana Supiana DOI: https://doi.org/10.31004/edukatif.v3i6.1522

Management.

Fikri, M. A. A., Pramono, T., Nugroho, Y. A., Novitasari, D., \& Asbari, M. (2021). Leadership Model In Pesantren: Managing Knowledge Sharing Through Psychological Climate. International Journal Of Social And Management Studies (Ijosmas), 2(03), 149-160.

Fornell, C., \& Larcker, D. F. (1981). Evaluating Structural Equation Models With Unobservable Variables And Measurement Error. Journal Of Marketing Research, 18(1), 39. Https://Doi.Org/10.2307/3151312

Ghozali, I. (2014). Structural Equation Modeling, Metode Alternatif Dengan Partial Least Square (Pls) (4th Ed.). Badan Penerbit Universitas Diponegoro.

Gold, A. H., Malhotra, A., \& Segars, A. H. (2001). Knowledge Management: An Organizational Capabilities Perspective. Journal Of Management Information Systems, 18(1), 185-214.

Hair, J. F., Black, W. C., Babin, B. J., \& Anderson, R. E. (2010). Multivariate Data Analysis (7th Ed.). Pearson Prentice Hall.

Hair, J. F., Hult, G. T., Ringle, C. M., \& Sarstedt, M. (2014). A Primer Partial Least Squaresstructural Equation Modeling (Pls-Sem). Sage Publications.

Hair, Joe F, Sarstedt, M., Ringle, C. M., \& Mena, J. A. (2012). An Assessment Of The Use Of Partial Least Squares Structural Equation Modeling In Marketing Research. Journal of The Academy Of Marketing Science, 40(3), 414-433.

Hair Jr, J. F., Sarstedt, M., Ringle, C. M., \& Gudergan, S. P. (2017). Advanced Issues In Partial Least Squares Structural Equation Modeling. Sage Publications.

Hutagalung, D., Asbari, M., Fayzhall, M., Ariyanto, E., Agistiawati, E., Sudiyono, R. N., Waruwu, H., Goestjahjanti, F. S., Winanti, \& Yuwono, T. (2020). Peran Religiusitas, Kepemimpinan Transformasional, Kepuasan Kerja Dan Mediasi Organizational Citizenship Behavior Terhadap Kinerja Guru. Edupsycouns: Journal Of Education, Psychology And Counseling, 2(1), 311-326. Https://Ummaspul.E-Journal.Id/Edupsycouns/Article/View/483

Hutagalung, D., Sopa, A., Asbari, M., Cahyono, Y., Maesaroh, S., \& Chidir, G. (2020). Influence Of Soft Skills, Hard Skills And Organization Learning On Teachers' Performance Through Innovation Capability As Mediator. Journal Of Critical Reviews, 7(19), 54-66. Http://Www.Jcreview.Com/?Mno=101978

Johan, M., Budiadnyana, G. N., Admiral, Asbari, M., \& Novitasari, D. (2021). Kepemimpinan Karismatik Dalam Perspektif Karyawan Umkm: Dari Motivasi Intrinsik Hingga Tacit Knowledge Sharing. Edumaspul: $\quad$ Jurnal Pendidikan, 5(1), 598-613. $\quad$ Https://Ummaspul.EJournal.Id/Maspuljr/Article/View/1303

Jumiran, Novitasari, D., Nugroho, Y. A., Sutardi, D., Sasono, I., \& Asbari, M. (2020). Pengaruh Dimensi Kepemimpinan Transformasional Terhadap Kepuasan Kerja Dan Komitmen Organisasional: Studi Kasus Pada Dosen Perguruan Tinggi Swasta. Edupsycouns: Journal Of Education, Psychology And Counseling, 2(1), 600-621. Https://Ummaspul.E-Journal.Id/Edupsycouns/Article/View/555

Maesaroh, S., Asbari, M., Hutagalung, D., Agistiawati, E., Basuki, S., Radita, F. R., Nurasiah, Yulia, Y., Singgih, E., \& Chidir, G. (2020). Pengaruh Religiusitas Dan Kepemimpinan Transformasional Terhadap Kinerja Guru Melalui Mediasi Organizational Citizenship Behavior. Edupsycouns: Journal Of Education, Psychology And Counseling, 2(1), 276-290. Https://Ummaspul.EJournal.Id/Edupsycouns/Article/View/473

Novitasari, D., \& Asbari, M. (2020a). Pengaruh Kepemimpinan Transformasional Terhadap Kinerja Karyawan: Peran Kesiapan Untuk Berubah Sebagai Mediator. Jurnal Manajemen, 10(2), 84-99. Https://E-Jurnal.Lppmunsera.Org/Index.Php/Jm/Article/View/2371

Novitasari, D., \& Asbari, M. (2020b). Urgensi Kepemimpinan Dan Mentalitas Siap Berubah Terhadap Kinerja Pegawai Di Masa Pandemi Covid-19. Jurnal Rekomen (Riset Ekonomi Manajemen), 4(1), 66-80. 
4581 Membangun Inovasi Organisasi: Antara Kepemimpinan Transformasional dan Proses Manajemen Pengetahuan - Dhaniel Hutagalung, Dewiana Novitasari, Nelson Silitonga, Masduki Asbari, Nana Supiana DOI: https://doi.org/10.31004/edukatif.v3i6.1522

Https://Jurnal.Untidar.Ac.Id/Index.Php/Rekomen/Article/View/2712

Novitasari, D., \& Asbari, M. (2021). Leaders Coaching Di Sekolah: Apa Perannya Terhadap Kinerja Guru? Edumaspul: Jurnal Pendidikan, 5(1), 580-597. Https://Ummaspul.EJournal.Id/Maspuljr/Article/View/1299

Novitasari, D., Asbari, M., Hutagalung, D., \& Amri, L. H. A. (2021). Mengelola Komitmen Dosen: Analisis Peran Modal Psikologis Dan Leaders Coaching. Value : Jurnal Manajemen Dan Akuntansi, 16(1), 198213. Https://E-Journal.Umc.Ac.Id/Index.Php/Vl/Article/View/1845

Novitasari, D., Asbari, M., Purwanto, A., Iskandar, J., Sutardi, D., Silitonga, N., \& Putra, A. S. (2020). Peran Social Support Terhadap Work Conflict, Kepuasan Dan Kinerja. Jurnal Penelitian Ilmu Manajemen (Jpim), 5(2), 187-202. Https://Doi.Org/Http://Dx.Doi.Org/10.30736\%2fjpim.V5i2.350

Novitasari, D., Asbari, M., Putra, F., Kumoro, D. F. C., \& Fikri, M. A. A. (2021). Tacit Knowledge Sharing Di Sekolah Islam: Analisis Kepemimpinan Dan Iklim Keamanan Psikologis. Cetta: Jurnal Ilmu Pendidikan, 4(2), 138-162. Http://Jayapanguspress.Penerbit.Org/Index.Php/Cetta/Article/View/1287

Novitasari, D., Asbari, M., \& Sasono, I. (2021). Pengaruh Religiusitas Dan Kualitas Pelayanan Terhadap Kepuasan Kerja. Jurnal Manajemen Strategi Dan Aplikasi Bisnis, 4(1), 117-130. Https://Doi.Org/Https://Doi.Org/10.36407/Jmsab.V4i1.268

Novitasari, D., Asbari, M., Sutardi, D., Gazali, G., \& Silitonga, N. (2020). Pengaruh Kesiapan Untuk Berubah Dan Efektivitas Kepemimpinan Transformasional Terhadap Kinerja Karyawan Di Masa Pandemi Covid19. Value: Jurnal Manajemen Dan Akuntansi, 18(2).

Novitasari, D., Asbari, M., Sutardi, D., Gazali, \& Silitonga, N. (2020). Mempertahankan Kinerja Karyawan Di Masa Pandemi Covid-19: Analisis Kesiapan Untuk Berubah Dan Efektivitas Kepemimpinan Transformasional. Value: Jurnal Manajemen Dan Akuntansi, 15(2), 22-37. Https://Doi.Org/Https://Doi.Org/10.32534/Jv.V15i2.1152

Novitasari, D., Goestjahjanti, F. S., \& Asbari, M. (2020). The Role Of Readiness To Change Between Transformational Leadership And Performance: Evidence From A Hospital During Covid-19 Pandemic. Apmba (Asia Pacific Management And Business Application), 9(1), 37-56. Https://Doi.Org/10.21776/Ub.Apmba.2020.009.01.4

Novitasari, D., Hutagalung, D., Amri, L. H. A., Nadeak, M., \& Asbari, M. (2021). Kinerja Inovasi Di Era Revolusi Industri 4.0: Analisis Knowledge-Oriented Leadership Dan Kapabilitas Manajemen Pengetahuan. Edukatif: Jurnal Ilmu Pendidikan, 3(4), 1245-1260. Https://Doi.Org/Https://Doi.Org/10.31004/Edukatif.V3i4.520

Novitasari, D., Sasono, I., Santoso, J., Sudiyono, R. N., \& Asbari, M. (2020). Pengaruh Kesiapan Untuk Berubah Pada Karyawan Manufaktur: Analisis Praktik Kepemimpinan Di Masa Pandemi Covid-19. Jumbo (Jurnal Manajemen , Bisnis Dan Organisasi ), 4(1), 175-188. Https://Doi.Org/Http://Dx.Doi.Org/10.33772/Jumbo.V4i1.13260

Novitasari, D., Supiana, N., Supriatna, H., Fikri, M. A. A., \& Asbari, M. (2021). The Role Of Leadership On Innovation Performance: Transactional Versus Transformational Style. Jimfe (Jurnal Ilmiah Manajemen Fakultas Ekonomi), 7(1), 27-36.

Novitasari, D., Supriatna, H., Asbari, M., Nugroho, Y. A., \& Nadeak, M. (2021a). Exploring The Impact Of Trust In Leader And Knowledge Sharing On Employee Innovation. International Journal Of Social And $\begin{array}{lll}\text { Management Studies } & \text { (Ijosmas), } & \text { 02(03), }\end{array}$ Https://Www.Ijosmas.Org/Index.Php/Ijosmas/Article/View/30

Novitasari, D., Supriatna, H., Asbari, M., Nugroho, Y. A., \& Nadeak, M. (2021b). Exploring The Impact Of Trust In Leader And Knowledge Sharing On Employee Innovation. International Journal Of Social And Management Studies (Ijosmas), 2(03), 47-62.

Nuryanti, Y., Novitasari, D., Nugroho, Y. A., Fauji, A., Gazali, \& Asbari, M. (2020). Meningkatkan 
4582 Membangun Inovasi Organisasi: Antara Kepemimpinan Transformasional dan Proses Manajemen Pengetahuan - Dhaniel Hutagalung, Dewiana Novitasari, Nelson Silitonga, Masduki Asbari, Nana Supiana DOI: https://doi.org/10.31004/edukatif.v3i6.1522

Komitmen Organisasional Dosen: Analisis Pengaruh Kepemimpinan Perguruan Tinggi Dan Kepuasan Intrinsik \& Ekstrinsik Dosen. Edupsycouns: Journal Of Education, Psychology And Counseling, 2(1), 561-581. Https://Ummaspul.E-Journal.Id/Edupsycouns/Article/View/551

Ooi, K.-B. (2009). Tqm And Knowledge Management: Literature Review And Proposed Framework. African Journal Of Business Management, 3(11), 633-643.

Prajogo, D. I., \& Hong, S. W. (2008). The Effect Of Tqm On Performance In R\&D Environments: A Perspective From South Korean Firms. Technovation, 28(12), 855-863.

Purwanto;, A., Asbari;, M., \& Santoso, P. B. (2019). Pengaruh Kompetensi, Motivasi, Kepemimpinan, Komitmen Dan Budaya Kerja Sistem Manajemen Integrasi Iso 9001, Iso 14000 Dan Iso 45001 Pada $\begin{array}{lllll}\text { Industri } \quad \text { Otomotif. } & \text { Jurnal } & \text { Produktivitas, }\end{array}$ Http://Openjurnal.Unmuhpnk.Ac.Id/Index.Php/Jp/Article/View/1798

Purwanto, A., Asbari, M., \& Santoso, P. B. (2020). Pengaruh Parenting Style Dan Personality Genetic Terhadap Pengembangan Pedidikan Karakter Anak Di Paud Islamic School. Quality, 8(1), 51. Https://Doi.Org/10.21043/Quality.V8i1.6606

Purwanto, A., Asbari, M., Santoso, P. B., Wijayanti, L. M., Hyun, C. C., \& Pramono, R. (2020). Effect Of Application Iso 38200:2018 Chain Of Wood Products Custody Toward Paper Company Competitiveness In Borneo Island Indonesia. International Journal Of Science And Management Studies (Ijsms), 3(2), $28-35$.

Purwanto, A., Asbari, M., \& Santoso, T. I. (2021a). Analisis Data Penelitian Manajemen Pendidikan: Perbandingan Hasil Antara Amos, Smartpls, Warppls, Dan Spss Untuk Jumlah Sampel Kecil. International Journal Of Social, Policy And Law (Ijospl), 01(01), 111-122. Https://Ijospl.Org/Index.Php/Ijospl/Article/View/64

Purwanto, A., Asbari, M., \& Santoso, T. I. (2021b). Education Management Research Data Analysis: Comparison Of Results Between Lisrel, Tetrad, Gsca, Amos, Smartpls, Warppls, And Spss For Small Samples. Nidhomul Haq: Jurnal Manajemen Pendidikan Islam, 6(2), 382-399. Https://EJournal.Ikhac.Ac.Id/Index.Php/Nidhomulhaq/Article/View/1575

Purwanto, A., Asbari, M., Santoso, T. I., Haque, M. G., \& Nurjaya. (2019). Marketing Research Quantitative Analysis For Large Sample: Comparing Of Lisrel, Tetrad, Gsca, Amos, Smartpls, Warppls, And Spss. Jurnal Ilmiah Ilmu Administrasi Publik: Jurnal Pemikiran Dan Penelitian Administrasi Publik, 9(2), 355-372. Https://Ojs.Unm.Ac.Id/Iap/Article/View/22803

Purwanto, A., Asbari, M., Santoso, T. I., Paramarta, V., \& Sunarsih, D. (2020). Social And Management Research Quantitative Analysis For Medium Sample: Comparing Of Lisrel, Tetrad, Gsca, Amos, Smartpls, Warppls, And Spss. Jurnal Ilmiah Ilmu Administrasi Publik: Jurnal Pemikiran Dan Penelitian Administrasi Publik, 9(2), 518-532. Https://Ojs.Unm.Ac.Id/Iap/Article/View/22804

Purwanto, A., Asbari, M., Santoso, T. I., Sunarsi, D., \& Ilham, D. (2021). Education Research Quantitative Analysis For Little Respondents: Comparing Of Lisrel, Tetrad, Gsca, Amos, Smartpls, Warppls, And Spss. Jurnal Studi Guru Dan Pembelajaran, 4(2), 335-350. Https://EJournal.My.Id/Jsgp/Article/View/1326

Sarstedt, M., Ringle, C. M., Smith, D., Reams, R., \& Hair Jr, J. F. (2014). Partial Least Squares Structural Equation Modeling (Pls-Sem): A Useful Tool For Family Business Researchers. Journal Of Family Business Strategy, 5(1), 105-115.

Silitonga, N., Johan, M., Asbari, M., Hutagalung, D., \& Novitasari, D. (2021a). Mengelola Kinerja Tim Engineering: Dari Iklim Kecerdasan Emosional Hingga Team Efficacy. Value : Jurnal Manajemen Dan Akuntansi, 16(1), 172-187. Https://E-Journal.Umc.Ac.Id/Index.Php/V1/Article/View/1839

Silitonga, N., Johan, M., Asbari, M., Hutagalung, D., \& Novitasari, D. (2021b). Mengelola Kinerja Tim Engineering: Dari Iklim Kecerdasan Emosional Hingga Team Efficacy. Value: Jurnal Manajemen Dan Akuntansi, 16(1), 172-187. 
4583 Membangun Inovasi Organisasi: Antara Kepemimpinan Transformasional dan Proses Manajemen Pengetahuan - Dhaniel Hutagalung, Dewiana Novitasari, Nelson Silitonga, Masduki Asbari, Nana Supiana DOI: https://doi.org/10.31004/edukatif.v3i6.1522

Silitonga, N., Novitasari, D., Sutardi, D., Sopa, A., Asbari, M., Yulia, Y., Supono, J., \& Fauji, A. (2020). The Relationship Of Transformational Leadership, Organizational Justice And Organizational Commitment: A Mediation Effect Of Job Satisfaction. Journal Of Critical Reviews, 7(19), 89-108. Http://Www.Jcreview.Com/?Mno=101999

Singgih, E., Iskandar, J., Goestjahjanti, F. S., Fahlevi, M., Nadeak, M., Fahmi, K., Anwar, R., Asbari, M., \& Purwanto, A. (2020). The Role Of Job Satisfaction In The Relationship Between Transformational Leadership, Knowledge Management, Work Environment And Performance. Solid State Technology, 63(2s), 293-314. Http://Www.Solidstatetechnology.Us/Index.Php/Jsst/Article/View/1556

Sutardi, D., Novitasari, D., Asbari, M., Silitonga, N., Nugroho, Y. A., Hutagalung, D., Mustofa, Chidir, G., Basuki, S., \& Yuwono, T. (2020). Pengaruh Work-Family Conflict, Stres Kerja Dan Social Support Terhadap Kepuasan Kerja: Studi Kasus Pada Guru Wanita Di Tangerang. Edupsycouns: Journal Of Education, Psychology And Counseling, 2(1), 482-498. Https://Ummaspul.EJournal.Id/Edupsycouns/Article/View/513

Wiratna, S. (2014). Metodologi Penelitian. In Pustaka Baru. Pt. Pustaka Baru.

Yusr, M. M., Mokhtar, S. S. M., Othman, A. R., \& Sulaiman, Y. (2017). Does Interaction Between Tqm Practices And Knowledge Management Processes Enhance The Innovation Performance? International Journal Of Quality \& Reliability Management.

Yuwono, T., Novitasari, D., Asbari, M., Sutardi, D., Mustofa, \& Asbari, M. (2020). Peran Organizational Commitment Terhadap Hubungan Work- Family Conflict Dan Kepuasan Kerja Karyawan Wanita Di Kota Seribu Industri Tangerang. Edupsycouns: Journal Of Education, Psychology And Counseling, 2(1), 524-540. Https://Ummaspul.E-Journal.Id/Edupsycouns/Article/View/526/303

Yuwono, T., Novitasari, D., Hutagalung, D., Sasono, I., Silitonga, N., \& Asbari, M. (2020). Peran Organizational Justice Terhadap Komitmen Organisasional: Analisis Mediasi Kepuasan Kerja Dosen Perguruan Tinggi Swasta. Edupsycouns: Journal Of Education, Psychology And Counseling, 2(1), 582599. Https://Ummaspul.E-Journal.Id/Edupsycouns/Article/View/550

Yuwono, T., Wiyono, N., Asbari, M., Novitasari, D., \& Silitonga, N. (2020). Analisis Pengaruh Efektivitas Kepemimpinan Transformasional Dan Kesiapan Untuk Berubah Terhadap Kinerja Karyawan Wanita Di Masa Pandemi Covid-19. Jurnal Ilmiah Mahasiswa Ekonomi Manajemen, 5(3), 615-632. Http://Www.Jim.Unsyiah.Ac.Id/Ekm/Article/View/15502

Zaman, M. N., Novitasari, D., Goestjahjanti, F. S., Fahlevi, M., Nadeak, M., Fahmi, K., Setiawan, T., \& Asbari, M. (2020). Effect Of Readiness To Change And Effectiveness Of Transformational Leadership On Workers ' Performance During Covid-19 Pandemic. Solid State Technology, 63(1s), 185-200. Http://Www.Solidstatetechnology.Us/Index.Php/Jsst/Article/View/708 